\title{
State-aid programs of BRICS countries: Case of transport equipment trade
}

\author{
A. G. Koval, A. B. Mogucheva \\ St. Petersburg State University, \\ 7-9, Universitetskaya nab., 199034, St. Petersburg, Russian Federation
}

For citation: Koval A. G., Mogucheva A. B. State-aid programs of BRICS countries: Case of transport equipment trade. St Petersburg University Journal of Economic Studies, 2018, vol. 34, issue 3, pp. 415438. https://doi.org/10.21638/spbu05.2018.304

State aid or subsidy programs are a common practice in developed and developing countries for supporting national companies. Despite the fact that they are strictly regulated by the WTO rules, BRICS countries actively apply this measure, even though they claim to adhere to the usual path of liberalization and trade cooperation. The aim of the paper is to reveal the distinguishing features of such programs in BRICS counties for trade in transport equipment. Using a cross-country comparative analysis and case studies, the authors first explain the controversy in theoretical approaches to state aid policy analysis. They then identify the peculiarities of non-tariff measures applied by BRICS and the role of state aid. Finally, the authors present data from specific case studies in transport equipment trade. The authors conclude that the effectiveness of subsidies in the transport sector is not obvious, as dynamics of imports and exports of relevant products depends on various external factors. Nevertheless, the application of state aid in the industry provides national producers a more favorable environment. State aid programs, in most cases, do not comply with WTO regulations, which implies trade distortion and could provoke trade disputes. BRICS countries should strengthen monitoring of these programs and focus on the opportunity for applying horizontal rather than vertical subsidies.

Keywords: state aid, subsidy, non-tariff measures, BRICS, protectionism, foreign trade, trade in transport equipment.

\section{Introduction}

In the turbulent global economy, countries often use various trade policy instruments to protect their producers in domestic and foreign markets. The world economic crisis of 2008-2009 influenced trade policy of both developed and developing countries and led to a phenomenon of "murky protectionism," when states applied trade distortive measures that did not directly violate World Trade Organization (WTO) rules [Baldwin, Evenett, 2009]. Since then, despite the international claims to facilitate trade through mutual liberalization, states have continued to implement more sophisticated protectionist practices.

Leaders of BRICS countries (Brazil, Russia, India, China, and South Africa) in recent meetings and summits announced the need for a "transparent, non-discriminatory, open

* This research was supported by the Russian Foundation for Basic Research (RFBR) No. 17-02-00688 "Transformation of Russian Foreign Economic Policy in a Changing Geopolitics".

(c) Санкт-Петербургский государственный университет, 2018 
and inclusive multilateral trading system" as well as "standstill and rollback of protectionist measures" and the increase of their cooperation in this field [BRICS Leaders ..., 2017]. Some scholars note a certain potential in promoting trade links among BRICS [Realizing the BRICS..., 2017]. However, the divergence in trade patterns of BRICS states has set off a debate about the limitations of such trade cooperation [Koval, Trofimenko, 2017; Pioch, 2017]. Moreover, one barrier to BRICS collaboration involves diversity in applied trade distortive measures. BRICS states differently execute protectionist policy to protect their domestic economies from tough competition and adverse effects of lower tariff rates. State aid (subsidies) is one of the most widely used measures implemented in many areas of domestic manufacturing, including transport equipment [Evenett, 2015].

The main goal of this paper is to investigate characteristics of state aid programs of BRICS states using cross-country comparative analysis with sectoral case studies. The research in this field usually uses country-level analysis of state aid in general or of support for a particular sector in a specific country. This paper contributes to existing studies by comparing different subsidy programs in various BRICS countries, which is less common in the literature. Moreover, this research will focus on trade distortions due to WTO inconsistency about state aid programs, which provides possible insights for academic work as well as for policy-makers implementing subsidies and estimating their impact.

The paper consists of the following parts. First, the theoretical review explains the controversy in approaches to and analyses of state aid policies and the importance of this study for the contemporary international trading system. Second, the paper identifies peculiarities of non-tariff measures applied by BRICS and the role of state aid for trade policies. Third, the authors conduct cross-country case studies for trade in transport equipment. Finally, the authors present concluding remarks.

\section{State aid as trade policy measures: theoretical background}

The concept of state aid has been widely debated among scholars and considerably varied across countries. State aids represent a significant amount of public funds and governments grant subsidies in a multiplicity of ways [Competition, State..., 2011]. In fact, according to majority of studies, state aid means the same as a subsidy and refers accordingly to non-tariff measures [Ginevicius et al., 2010; Messerlin, 1999; Zahariadis, 2008].

The existence of the seemingly identical notions "state aid" and "subsidy" might be due to differences in relevant rules for the European Union (EU) and WTO. The term "state aid" is widely used in EU legal documents, whereas "subsidy" describes similar practices in WTO agreements. ${ }^{1}$. The European law defines state aid as "an advantage in any form whatsoever conferred on a selective basis to undertakings by national public authorities." To be "state aid" in the meaning of EU legislation, a measure must have the following features: 1) There should be an intervention by the state or through state resources that can take a variety of forms (e.g. grants, interest and tax relief, guarantees, state holdings of all or part of a company, providing goods and services on preferential terms, etc.); 2) The intervention should provide the recipient an advantage on a selective basis, for example to specific companies or industry sectors, or to companies located in specific regions; 3) Competition should be or may be distorted; 4) Intervention is likely to

${ }^{1}$ The comparative analysis of juridical discrepancy for 'state aid' and 'subsidy' in the EU and the WTO accordingly is represented in the study by Luca Rubini [Rubini, 2009]. 
affect trade between Member States [Competition, State..., 2017]. The WTO Agreement on Subsidies and Countervailing Measures (SCM Agreement) defines a subsidy as "a financial contribution by a government or any public body within the territory of a WTO Member, involving actual or potential direct transfer of funds (e.g. grants, loans, equity infusions) or liabilities (loan guarantees), government revenue that is otherwise due is foregone or not collected, the provision of goods or services other than general infrastructure or purchases of goods, making payments to a funding mechanism, or entrusting or directing a private body to carry out one or more of the type of functions listed above, providing any form of income or price support ${ }^{2} \ldots$ which operates directly or indirectly to increase exports of any product from, or to reduce imports of any product into the territory of a WTO Member"3.

As one can see from these definitions, state aid or subsidy is any form of public contribution to private companies, and the main issue is how significantly this measure alters competition and trade flows between states. The focus of the WTO is more precisely on trade effects. A WTO Member State could challenge a trade-distorting subsidy granted by another Member State via the Dispute Settlement Mechanism (DSM) or could implement countervailing duties. However, initiation of both a dispute in the WTO or a countervailing measure is costly, so in some cases Member States prefer to implement their own subsidy programs in response. This can cause a chain reaction and further increases in state aid. One important difference is that the EU system provides both ex-ante and ex-post control of state aid, while the WTO assumes only ex-post control through DSM [Competition, State..., 2011]. In the EU system all subsidies should be proven by the European Commission, while in the WTO there is only a notification procedure. This explains why there is a rise of state aid programs implemented by the WTO Members (including the EU) to support domestic producers in the competition with foreign producers both on national and international markets.

According to information from the Global Trade Alert (GTA) database - the most complete and comprehensive database compiling state measures from countries all over the globe likely to discriminate foreign commercial interests ${ }^{4}-$ state aid and bailouts ${ }^{5}$ are the most widely used measures worldwide (Table 1). State aid is rated first among measures already implemented and classified as $\mathrm{red}^{6}$ (third among pending measures), and are in the top three types of measures affecting the largest number of sectors, tariff lines, and jurisdictions.

${ }^{2}$ Agreement on Subsidies and Countervailing Measures, Article I // WTO. 24-scm.pdf. 229 p. Available at: https://www.wto.org/english/docs_e/legal_e/24-scm.pdf (accessed: 15.02.2018).

3 General Agreement on Tariffs and Trade 1947, Article XVI // WTO.gatt47.pdf. Geneva, 1986. 97 p. Available at: https://www.wto.org/english/docs_e/legal_e/gatt47_e.pdf (accessed: 15.02.2018).

4 The Global Trade Alert database has involved government statements made after November 2008 until present time which included a credible announcement of a meaningful and unilateral change in the relative treatment of foreign versus domestic commercial interests. It covers 233 countries and dependent territories. More information on data classification and methodology in the GTA handbook: Evenett S. J., Fritz J. The Global Trade Alert database handbook. Manuscript, 28.03.2018. Available at: file:///C:/Users /\%D0\%A1\%D0\%B5\%D1\%80\%D0\%B3\%D0\%B5\%D0\%B9/Downloads/GTA\%20handbook.pdf (accessed: 15.05.2018).

${ }_{5}$ Bail-out means "the provision, usually by a government, of funds to a firm or to another government in danger of insolvency so as to prevent them from defaulting on their debt" [Deardroff, 2014]. Bail-out therefore is a specific type of state aid particularly applied in the period of economic crisis.

${ }^{6}$ Measures indicate governmental actions already taken and almost certainly discriminating against foreign commercial interests. 
Table 1. Trade policy measures worldwide that affect foreign trade, 2008-2016

\begin{tabular}{|l|c|c|c|c|c|c|c|}
\hline \multicolumn{1}{|c|}{ Measure type } & $\begin{array}{c}\text { Measures } \\
\text { reported }\end{array}$ & $\begin{array}{c}\text { Measures } \\
\text { classifies } \\
\text { red }\end{array}$ & $\begin{array}{c}\text { Measures } \\
\text { already } \\
\text { implemented }\end{array}$ & $\begin{array}{c}\text { Pending } \\
\text { measures }\end{array}$ & $\begin{array}{c}\text { Jurisdictions } \\
\text { affected }\end{array}$ & $\begin{array}{c}\text { Tariff } \\
\text { lines } \\
\text { affected }\end{array}$ & $\begin{array}{c}\text { Sectors } \\
\text { affected }\end{array}$ \\
\hline State aid / Bail-out & 2114 & 1833 & 1634 & 480 & 214 & 729 & 63 \\
\hline Import tariff & 1981 & 705 & 1355 & 626 & 201 & 457 & 60 \\
\hline $\begin{array}{l}\text { Trade defense } \\
\text { measure (AD, CVD, } \\
\text { safeguard) }\end{array}$ & 1895 & 1424 & 1191 & 704 & 107 & 998 & 64 \\
\hline $\begin{array}{l}\text { Export taxes or } \\
\text { restrictions }\end{array}$ & 742 & 371 & 397 & 345 & 194 & 1031 & 69 \\
\hline Investment measure & 618 & 211 & 531 & 87 & 170 & 1205 & 65 \\
\hline $\begin{array}{l}\text { Public procurement } \\
\text { localization }\end{array}$ & 503 & 396 & 288 & 215 & 161 & 49 & 38 \\
\hline Trade finance & 478 & 405 & 410 & 68 & 198 & 211 & 24 \\
\hline $\begin{array}{l}\text { Localization } \\
\text { requirement }\end{array}$ & 468 & 346 & 397 & 71 & 207 & 445 & 49 \\
\hline $\begin{array}{l}\text { Non tariff barrier } \\
\text { (not otherwise } \\
\text { specified) }\end{array}$ & 457 & 181 & 333 & 124 & 196 & 283 & 37 \\
\hline
\end{tabular}

S o u r c e: Global Dynamics // Global Trade Alert (GTA). 2008-2016. Available at: https://www. globaltradealert.org/global_dynamics (accessed: 15.02.2018).

On the one hand, even though the impact of state aid has a distorting effect on competition domestically and internationally [Collie, 2000], state aid is effective for increasing financial viability of national companies and their survival in crisis periods [Heima et al., 2017]. As economic and financial crises forced anti-competitive responses by governments, the recent crisis of 2008-2009 evidently catalyzed the demand for stronger state protection of the most vulnerable constituent parts of the economy and society to promote quicker recovery. Subsidies in this case gave more support for competing with foreign companies in the domestic market.

On the other hand, subsidies are universally acknowledged to be not only a widely used protectionist instrument, but also an effective means to stimulate exports. Economists believe export flows (especially those to developed countries) are a universal indicator reflecting competitiveness of domestically produced goods, demand in foreign markets, and conformity with international standards [Poluektov, 2015]. Statistics show that subsidies are widely used by governments of different countries as effective incentives for exports, which has become a threat to all efforts of trade liberalization to reduce the effect of tariff rate reductions. The way subsidies have potential to do so is through distorting competition. In this case, a recipient of state aid obtains benefits not granted under common market conditions [Sciskalova, Muenster, 2014].

Economic reasoning presupposes that subsidies can be justified only under very specific circumstances; nevertheless, in the majority of cases they do not rely on purely 
economic grounds. Very often logrolling becomes the driving reason for implementing subsidies; in this case, the economy is unlikely to end up in a situation of efficient resource allocation, but it may have desirable political benefits [Houthakker, 1972].

It is also worth to mentioning that in some cases subsidies constitute the greatest part of state expenditures. They directly influence domestic resource allocation, income distribution, and state expenditure productivity, and reduce the flexibility of the economy, affecting structural and/or sectoral adjustments [Schwartz, 1999]. Governments use state aid to alter economic activity and and to generate employment so as to achieve an outcome that would not otherwise appear. Subsidies may create jobs, increase productivity, and promote further private investment. Nevertheless, producers may be prone to mimic companies-in-need, for example, underinvesting in $\mathrm{R} \& \mathrm{D}$ - subsidizing firms that exceed an established threshold of $\mathrm{R} \& \mathrm{D}$ investment is one way to deal with this problem.

The justification of state aid is compensation for market failures and market imperfections [Meiklejohn, 1999]. When it becomes a tool "to make use of" rather than to "correct" market imperfections, it may improve social security at home [Abbott et al., 1987; Feenstra, 1986]. For instance, in the case of a market failure, the "first-best" policy to address a single distortion offsets the source of the distortion directly: if domestic production of a certain good is associated with positive externalities, a production subsidy is the "first-best" policy, as it is welfare-superior to an import tariff [Trade and public policies..., 2012]. The major problem is that the choice of "treatment" often depends on initial costs rather than on forecasts of possible net returns [Shah, 2005].

Being a non-market instrument, subsidies can hardly be called the best available policy alternative. However, due to the decrease in opportunities to use tariffs for protectionism in the contemporary international trading system, governments focus on state aid as one available non-tariff measure. In order to estimate the economic burden of subsidies of any kind, policymakers need to align their actions with several factors. Initially transparency - the first but not the decisive factor - means quite a bit; undisclosed costs and benefits can hamper subsidy control and economic development connected with it.

Second, there is empirical evidence that means-testing, categorical targeting, or selftargeting of state-aid recipients can increase efficiency and reduce fiscal burden for citizens when compared to blanket subsidies that neither target separate groups of beneficiaries, nor establish any threshold values above which consumers and/or producers will not get state support. This preserves the effectiveness of subsidy programs [Report from the Commission..., 2011]. Third, policymakers must be aware of beneficiaries' willingness to change their economic behavior to further obtain gains from state subsidy programs; this is why periodic reassessment of the efficiency of subsidies is required, along with retargeting or elimination, and intensive control over costs and cost recovery. Fourth, state aid programs should be structured in line with states' institutional and administrative wherewithal [Głowicka, 2008].

Governments in developed and developing countries tend to use multiple policies with various tariff and non-tariff instruments. The main objectives for using subsidies are industrial development, innovation, and support for national champions, environmental conservation, and redistribution [Exploring the links..., 2006]. The first mentioned refers to the most common goal of state aid for developing countries and emerging markets. BRICS states widely use subsidies in their industrial policies [Naude et al., 2015]; however, there is a certain lack of comparative studies in this field. 


\section{State aid in the context of BRICS trade policies: overview}

BRICS trade policies are relatively diverse: they use both liberalizing and protectionist trade policy measures. However, the number of restrictive measures prevails over those that liberalize, and there are some claims that most instruments for trade liberalization are only temporary and that BRICS undertake more comprehensive approaches to protectionism [Barone, Bendini, 2015; Evenett, 2015]. BRICS countries apply a mixed variety of tariff and non-tariff instruments that affect intra-BRICS trade as well [Koval, Pioch, 2017]. Table 2 presents the structure of the most popular trade policy measures among BRICS countries, as reported to the Global Trade Alert Database for the period 2008-2016.

For the above-mentioned period, BRICS states altogether implemented 311 state aid programs. For all BRICS states, except India, state aid was among top five implemented measures; however, India enacted a substantial amount (30) of state aid programs in comparison with South Africa (5) or China (19). Russia applied almost $70 \%$ of all BRICS subsidy programs. We suppose that such variation in the application of state aid programs is a function of several factors. First, it is positively correlated with the level of domestic production competitiveness in global markets. For instance, according to the Global Manufacturing Competitiveness Index Report 2016, China secured the leading position, while India was 11th in the ranking; South Africa, Brazil, and Russia were $27^{\text {th }}, 29^{\text {th }}$, and $32^{\text {th }}$ [Global Manufacturing ..., 2016]. This means that Brazil and Russia ceteris paribus needed more state support for industrial development. However, such support might include not only state aid or similar trade measures, but also investment in improving the business climate, such as the legal and institution framework. A significant amount of state aid in Russia could be also due to its opportunity to conduct such trade policy independently during the world economic crisis of 2008-2009, when Russia was not yet a WTO member (which Russia joined in 2012).

Table 2. Top-5 non-tariff measures affecting foreign commercial interests used by BRICS in 2008-2016

\begin{tabular}{|l|l|c|c|c|c|c|}
\hline \multicolumn{1}{|c|}{ Measure } & \multicolumn{1}{|c|}{ Russia } & Brazil & China & $\begin{array}{c}\text { South } \\
\text { Africa }\end{array}$ & India \\
\hline 1 & State aid / bail-out & 217 & 40 & 19 & 5 & 30 \\
\hline 2 & Import tariff & 64 & 53 & 27 & 52 & 46 \\
\hline 3 & Export taxes or restrictions & 23 & - & - & - & - \\
\hline 4 & Trade finance & 21 & - & - & - & 113 \\
\hline 5 & Public procurement localization & 20 & - & - & 3 & - \\
\hline 6 & $\begin{array}{l}\text { Trade defense measures (antidumping, } \\
\text { countervailing, safeguard) }\end{array}$ & - & 90 & 45 & 23 & 158 \\
\hline 7 & Localization requirement & - & 50 & - & 3 & 120 \\
\hline 8 & Export incentive & - & 9 & 26 & - & 40 \\
\hline 9 & Investment measure & - & - & 20 & - & - \\
\hline
\end{tabular}

Note: Compiled by the authors based on the GTA Database: Countries // Global Trade Alert (GTA). 2008-2016. Available at: https://www.globaltradealert.org/countries (accessed: 15.02.2018). 
A second factor is the government's disposition to protectionism or liberalization. Although the majority of measures implemented by each BRICS state were protective, the balance between liberalizing and protective measures differed across these countries. Thus, states with the most protective trade policies were India and Russia, who applied $28 \%$ liberalizing and $72 \%$ harmful measures between November 2008 and February 2018, according to the GTA database. In the same period, Brazil liberalized trade the most among BRICS, as it implemented $47 \%$ liberalizing and $53 \%$ harmful measures. South Africa and China took positions in the middle: $42 \%$ and $40 \%$ liberalizing, versus $58 \%$ and $60 \%$ harmful measures, respectively.

Third, if a country is not inclined to use state aid programs with further subsidies as defined in the WTO SCM Agreement, it uses alternative means to promote local products promotion in exports markets: localization requirements, export incentives, trade finance, and so on. For instance, Table 2 shows that Brazil, China, and India prefer trade defense measures, and South Africa used more tariff barriers than non-tariff policies.

The foreign markets most affected by protective measures applied by BRICS are for motor vehicles and components, chemicals, metal products, and electronics. BRICS countries, especially Russia, use state aid programs most actively in trade of transport equipment. According to the Harmonized Commodity Description and Coding System (HS), transport equipment is exported and imported under these codes: 86 (Railway or tramway locomotives, rolling stock and parts thereof); 87 (Vehicles other than railway or tramway rolling stock, and parts and accessories thereof); 88 (Aircraft, spacecraft, and parts thereof); and 89 (Ships, boats, and floating structures). The role of transport equipment production for BRICS manufacturing is relatively high. According to World Bank data, the share of transport and machinery equipment in manufacturing value added was estimated to be more than $25 \%$ for China, $22 \%$ for Brazil, $20.5 \%$ for India, $14 \%$ for South Africa, and $10.5 \%$ for Russia ${ }^{7}$.

In 2017, BRICS share in global export of transport equipment was estimated at $8.3 \%$, and for import at $9.3 \%$. China occupies the lion's share of trade in transport equipment among BRICS; however, the share of these products in national export for South Africa, Brazil, and India was higher than for China (cf. Table 3). Russian exports of transport equipment accounted for only $2 \%$ of national exports, while imports made up more than $13.9 \%$ of the country's total imports. Russia demonstrated the most unbalanced trade in transport equipment, with a relatively high value of negative trade balance.

In general, for 2008-2016 both BRICS export and import of transport equipment increased, while the most significant development was motor vehicle trade (HS 87), where export growth was more significant than import growth. The most substantial leap in exports was for India. The export of motor vehicles from India increased 3.5 times for 2008-2016, while exports from China and South Africa almost doubled. At the same time, it is notable that exports of the same products from Russia and Brazil slightly decreased. The main question is whether these changes rely on state aid programs.

7 The World Bank presents the only database that makes it possible to compare the role of machinery and transport equipment for BRICS manufacturing. However, this indicator includes not only transport equipment, but also computing, communication, and other equipment. The latest year of measurement was 2013. However, this still provides an overview of the significance of transport equipment sectors for BRICS (World Development Indicators Database // World Bank. 2013. Available at: https://data.worldbank.org/ products/wdi (accessed: 15.05.2018)). 
Table 3. BRICS trade in transport equipment in 2017

\begin{tabular}{|l|c|c|c|c|c|c|}
\hline Countries & $\begin{array}{c}\text { Export, } \\
\text { USD, bln }\end{array}$ & $\begin{array}{c}\text { Share in } \\
\text { national } \\
\text { export, \% }\end{array}$ & $\begin{array}{c}\text { Share in } \\
\text { world } \\
\text { export, \% }\end{array}$ & $\begin{array}{c}\text { Import, } \\
\text { USD, bln }\end{array}$ & $\begin{array}{c}\text { Share in } \\
\text { national } \\
\text { import, \% }\end{array}$ & $\begin{array}{c}\text { Share in } \\
\text { world } \\
\text { import, \% }\end{array}$ \\
\hline Brazil & 20.58 & 9.5 & 1 & 12.76 & 8.5 & 0.5 \\
\hline Russia & 7 & 2 & 0.4 & 31.8 & 13.9 & 1.7 \\
\hline India & 16.63 & 7.7 & 0.9 & 12.3 & 3.6 & 0.7 \\
\hline China & 104.9 & 4.6 & 5.4 & 108.1 & 5.9 & 5.9 \\
\hline South Africa & 10.59 & 12 & 0.6 & 8.3 & 10 & 0.5 \\
\hline
\end{tabular}

Note: Compiled by the authors based on the information of ITC Trade Map Database: Trade Map Database // International Trade Centre. 2018. URL: https://trademap.org/Index.aspx? AspxAutoDetectCookieSupport=1 (accessed: 15.05.2018).

\section{Methodology}

In order to compare and assess possible adverse effects of BRICS state aid programs on trade in transport equipment, we chose the case study method for the following reasons. First, the cases provide a new perspective on a relatively underexplored subject and can be considered an initial step in research. Case studies allow us to conduct an in-depth analysis of real situations and indicate specific features of state aid programs. Second, the analysis of BRICS cases allows a comparative study. The contrast of cases could present valuable findings. Finally, the case study method involves both qualitative and quantitative analyses. As state aid could be provided in different forms and a variety of approaches (due to differences in objectives, pre-conditions, economic and political environments, etc.), there are constrains of sole use of quantitative methods ${ }^{8}$. Exogenous factors must also be included in the analysis. For example, a decision to provide subsidies to some producers but not others may arise not out of pure necessity of rescuing an enterprise or an industry, but also out of political efforts by elites or lobbying groups, or poor macroeconomic policies. Not taking such factors into account might lead to the wrong conclusions: correct assessment of a starting point for the implementation of a subsidy programe is crucial for further analysis. Therefore, the analysis of trade statistics, on the one hand, and the detailed study of provisions of state aid programs, on the other, will help us make certain assessments and recommendations. The qualitative analysis will be based on the nonconformity of BRICS state aid programs with WTO norms.

Evaluating state aid requires a unified framework accepted by all analytical units (i.e. BRICS countries), because if there is no such framework or if it is not agreed that countries must conform to some uniform requirements, a researcher may come to wrong conclusions. Some common rules should serve as a basis for analysis: being aware of regulations

${ }^{8}$ In studies of state aid provided in the European countries one may find a usage of mono method, e. g. quantitative one. However, the statistical and econometric analysis of the EU state aid is visible as it is provided in a single manner due to the common regulation. BRICS states apply different legislation and approaches in their subsidy programmes that complicates the analysis with a wide range of limitations. 
that their legislation should meet, countries do better or worse adjusting their domestic legislation.

We test the potential for BRICS state-aid programs to distort trade in terms of their consistency with WTO legislation, taking into account that there is no other commonly accepted legal basis to compare trade policies of BRICS states; and the WTO definition of "subsidies" is relevant for BRICS, as they all are WTO Members. We assume that a violation of any WTO Agreement has an adverse effect on trade as agreed between WTO members and stated in the Preamble to the Agreement GATT 1947. Because Russia acceded to the WTO in 2012, we searched for relevant state aid programs in BRICS for 2012-2016 ${ }^{9}$. During the chosen period, subsidy programs for transport equipment trade were implemented by four out of five BRICS members, China being the exception. We suggest that China did not apply state aid programs because Chinese goods were already competitive, and so there was no need for China to use additional non-market incentives to improve their situation. According to Euromonitor, China accounts for $59 \%$ of transport equipment production value in Asia Pacific and remains one of the world's growth drivers. Asia Pacific will outperform Western Europe and North America as the Chinese transport equipment industry is forecast to expand at a compound annual growth rate of $8 \%$ in 2016-2025 [Euromonitor..., 2018]. Bail-outs as a form of state aid for the crisis period occurred when the necessity arose to rescue a sector or enterprise from bankruptcy; the Chinese economy has been stable and managed to avoid such situations in sectors of production with a high share of state control, which provided conditions good enough to keep key market players afloat. Instead of subsidizing domestic producers, the Chinese government imposed trade defense measures under the auspices of WTO membership, which seems enough for the development in this field in comparison with other BRICS states, such as India, which applied a variety of trade policy instruments (e.g. subsidies and trade defense measures).

The choice of the state aid programs for the case studies was made according to the following criteria. First, the program needs to be a comprehensive, long-term project, not a one-use, and it should continue throughout the period 2012-2016. Second, the program should not be aimed at one particular region of a country, as its key objective should be national industrial development.

The only programs suitable for these criteria in South Africa and India are, respectively, the "Automotive Investment Scheme" and "Make in India" policies. We chose INOVARAuto program for Brazil, as consultations within the WTO dispute settlement mechanism have already been requested by the EU and Japan, and the dispute now is under revision of the WTO Appealed Body. The Brazilian experience is interesting, as this dispute is one of few cases brought under the SCM Agreement in the transport equipment sector ${ }^{10}$.

For this period in Russia, overthirty state aid programs affecting trade in transport equipment were initiated. The bulk of these related to the automobile and aviation indus-

9 The data for 2017 was not still available for the analysis for all countries.

10 From the historical perspective of BRICS trade in transport equipment, another dispute via the SCM Agreement was earlier initiated by the USA against China in September 2012. However, it referred to export subsidies (not bailouts or state aid) and other incentives for automobile and automobile parts enterprises in China. The dispute was resolved at the consultation stage, as China ended this type of support: DS450: China - Certain Measures Affecting the Automobile and Automobile-Parts Industries // World Trade Organization (WTO). Dispute Settlement. 20.11.2012. Available at: https://www.wto.org/english/ tratop_e/dispu_e/cases_e/ds450_e.htm (accessed: 15.05.2018). 
tries. However, subsidies for the automobile sector were mostly short-term or recently implemented. Moreover, they concerned a specific type of support, for example stimulus measures for the automobile sector for partial coverage of $\mathrm{R} \& \mathrm{D}$ and testing expenses applied in January 2014, or state-supported preferential leasing schemes for the local car industry implemented in May 2015. They have not represented general-purpose programs, as they were applied in other BRICS states, and this would have made our comparison problematic. For this reason, for the Russia's case we have chosen the Aviation Industry Development 2013-2025 program, which seemed similar to state aid cases selected for Brazil, India, and South Africa.

\section{State aid impact on BRICS trade in transport equipment: case studies findings}

\section{Brazil: INOVAR-Auto program}

Brazil, like other developing countries, has been concerned with boosting its industry through innovative and competitive production, focusing state actions on technological development [Pereira, 2009]. INOVAR-Auto was approved in Brazil on October 2012 by Law No. 12.715/2012. The main goal of this program was to create conditions for increasing competitiveness in the automotive sector, producing more fuel efficient vehicles, and investing in the supply chain and development of technology. Support was provided through presumed IPI (Tax on Industrialized Products) tax credits granted to accredited companies or through reduced IPI tax rates on imports of vehicles originating in certain countries, as well as on certain domestic vehicles [Brazil - Certain Measures..., 2017]. The reduction of IPI tax could be up to $30 \%$. The duration of the program was five years, from 2013 to 2017 . Since 2017, the reduction of IPI tax is $1-2 \%$ for certain vehicles [INOVAR-Auto, 2018].

The INOVAR-Auto program set up in Brazil seems to distort trade by providing more favorable treatment to domestically produced goods and goods originating from territories of some WTO members, such as Mexico and MERCOSUR ${ }^{11}$ countries, granting no such treatment for goods imported from other WTO members [Brazil - Certain Measures..., 2017]. One might argue that Brazil could provide more favorable treatment in the framework of MERCOSUR and a regional trade agreement (RTA) with Mexico; however, INOVAR-AUTO concerned internal taxation that was not a subject to such RTAs.

Thus, the Brazilian program does not provide "no less favorable" treatment to WTO members based on the following appraisal. First, it does not immediately and unconditionally grant all advantages, privileges, or immunities, in particular tax advantages available only to vehicles imported from MERCOSUR and Mexico, in accordance with GATT Article I (Most Favoured Nation (MFN) Treatment). Second, INOVAR-Auto imposes the IPI tax on imported vehicles in excess of that imposed on similar domestic products, and so domestically produced goods receive a higher level of protection, violating GATT Article III (National Treatment). Third, it provides better conditions for accreditation of domestically produced motor vehicles, automotive components, and tools than of those imported into Brazil. Finally, the program establishes criteria and requirements to benefit

${ }^{11}$ MERCOSUR (Southern Common Market) is a customs union uniting Argentina, Brazil, Paraguay and Uruguay. 
from tax advantages under INOVAR-AUTO, including the requirement to perform certain manufacturing procedures in Brazil, and basing the reduction of IPI tax credits on the level of local content in automotive components. This essentially violates the WTO Agreement on Trade-Related Investment Measures (TRIMs). In summary, the Brazilian government provided a subsidy prohibited under the Article III SCM Agreement, as it was contingent on the use of domestic over imported components.

All these arguments were presented by the $\mathrm{EU}$, which initiated a dispute against Brazilian programs, including INOVAR-Auto, in 2013; Japan introduced the same claim in 2015. In 2017 the Panel issued a report that agreed with the EU and Japan and stated that INOVAR-Auto was WTO-inconsistent. On September 28, 2017, Brazil claimed it would appeal certain legal interpretations of the panel report to the Appellate Body [DS472..., 2018]. Thus, the dispute is still under consideration. The final decision will likely be against Brazil and indicate that such state aid is WTO-inconsistent and distorts trade. However, this decision will likely be made when the program is ended. This is a clear example of how WTO members can apply trade distortive subsidies for a certain period of time without penalties, as DSM decisions do not have a retroactive effect.

Analyzing trade in motor vehicles (87 HS Code), we could see that Brazilian exports substantially increased in 2012-2013, although in 2013-2016 there was a fall in export volumes (Figure 1). Imports have also declined, more substantially than exports. In 2016 Brazil had a positive trade balance for the first time since the state aid program was initiated.

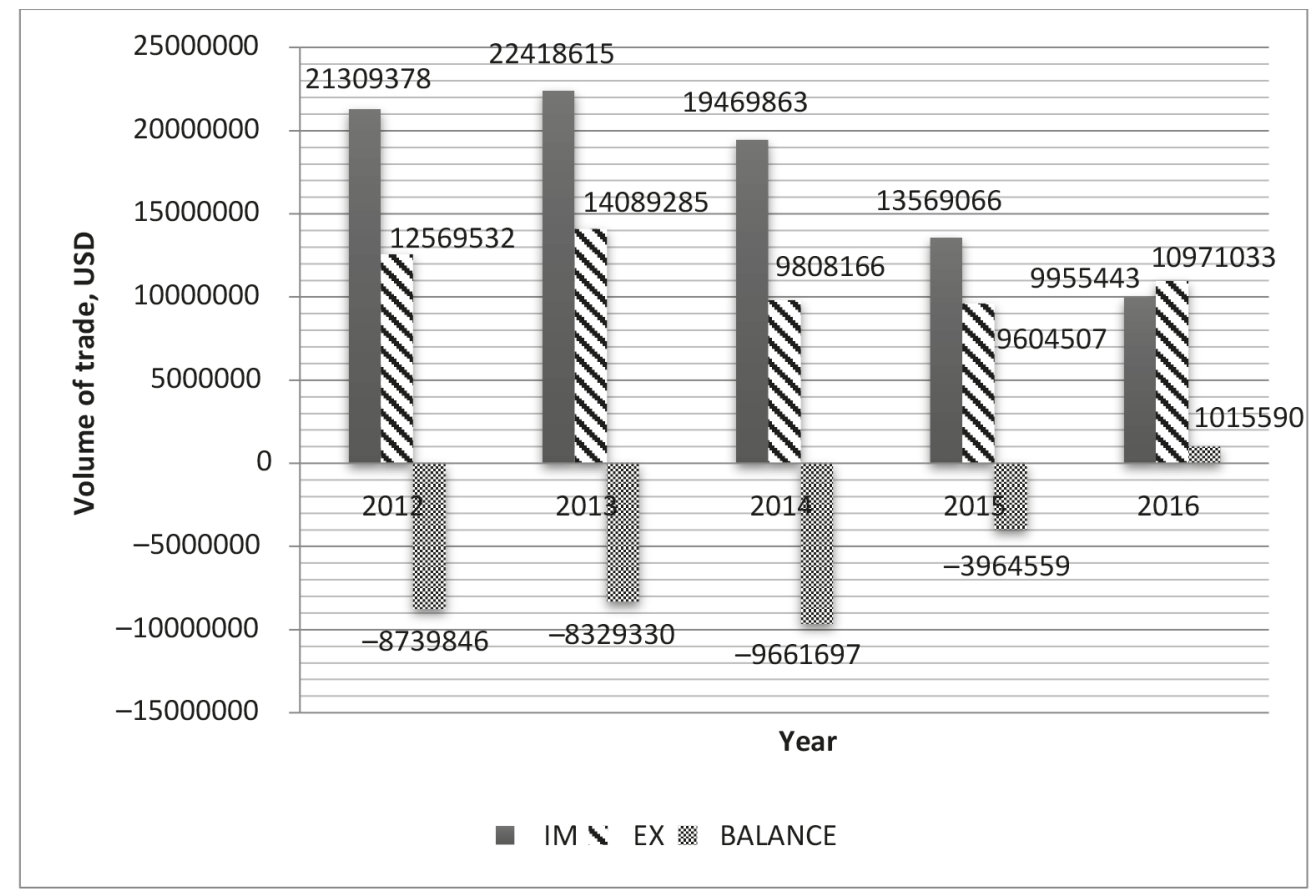

Figure 1. Brazilian 87 HS Code Commodities Trade Balance

N o t e: Compiled by the authors based on the information of ITC Trade Map Database: Trade Map Database // International Trade Centre. 2018. Available at: https://trademap.org/Index.aspx?AspxAutoDetectCookieSupport=1 (accessed: 15.02.2018). 
One could argue that such changes in trade balance are an obvious outcome of INOVAR-Auto that increased competitiveness of national producers. However, this result may be attributed to falling domestic demand, causing falling imports [Biller, 2015], or to a devaluation of the Brazilian currency, making Brazilian goods less expensive and increasing their competitiveness [Sambo, Godboy, 2015]. Nevertheless, some experts argue that INOVAR-Auto program was very promising in the development of R \& D activities, increasing energy efficiency, and dealing with environmental issues [Mello et al., 2016]. Another study does not see an increase in overall R \& D efforts and innovation, and highlights that over-investment did not increase scale efficiency and productivity level [Sturgeon et al., 2017]. Therefore, Brazilian state aid INOVAR-Auto made its contribution to enhance the competitiveness of the automotive sector; however, industrial development was not very substantial [Pascoal et al., 2017] and other factors (for instance, an overall economic downturn in Brazil) played their role in trade dynamics.

\section{Russia: Aviation Industry Development 2013-2025 program}

In 2012 (revised March 31, 2017) the Ministry of Industry and Trade of the Russian Federation adopted a governmental strategy for the aviation industry aimed at creating favorable conditions to gain global competitiveness and strengthen Russia's position on the world market in terms of production volumes (as the country currently is ranked third globally by volume of aircraft production). Among the objectives outlined in the text of the strategy was creating incentives for purchasing Russian-made aircraft and implementing state-support measures for the industry in accordance with WTO requirements. The former is the major goal of one of the sub-programs, Aviation Industry Development 2013-2025, that establishes an opportunity to obtain state aid for aircraft producers operating on the territory of the Russian Federation [Resolution of March..., 2013].

A subsidy can be granted to passenger aircraft producers to cover costs of initial spare part stock formation, ground support equipment provision, and aircraft personnel retraining. An applicant should have a license for aircraft construction, production, testing, and maintenance, and not be indebted. The volume of a subsidy granted can amount to 0.9 of the producer's costs of spare part stock formation, ground support equipment provision, and aircraft personnel retraining; the maximum volume of all the costs per one aircraft taken into account cannot exceed RUR $115 \mathrm{mln}$ (for an aircraft with passenger capacity of 95-110 seats and maximum takeoff weight of 45-52 tons) or RUR 120 mln (for an aircraft with passenger capacity of 135-211 seats and maximum takeoff weight of 65-80 tons). The total number of aircraft taken into consideration for a subsidy calculation cannot exceed 100 units for both the types of aircraft described above. The subsidy is provided once, ex post and pre-payment is not allowed.

As clearly stated in the text of the program, subsidies can be granted to cover costs of aircrafts, produced on the territory of the Russian Federation not earlier than on the 1st of January 2015 and no later than 31st of December 2022. In fact, there have been only two aviation companies manufacturing aircraft of the identified capacity on Russian territory: Sukhoi Aviation Holding Company (JSC), producing the Sukhoi Super Jet with a passenger capacity of 95-110 seats; and IRKUT Corporation, producing MC-21 passenger aircraft with passenger capacity of 195-210 seats, both belonging to and managed by United Aircraft Corporation. 


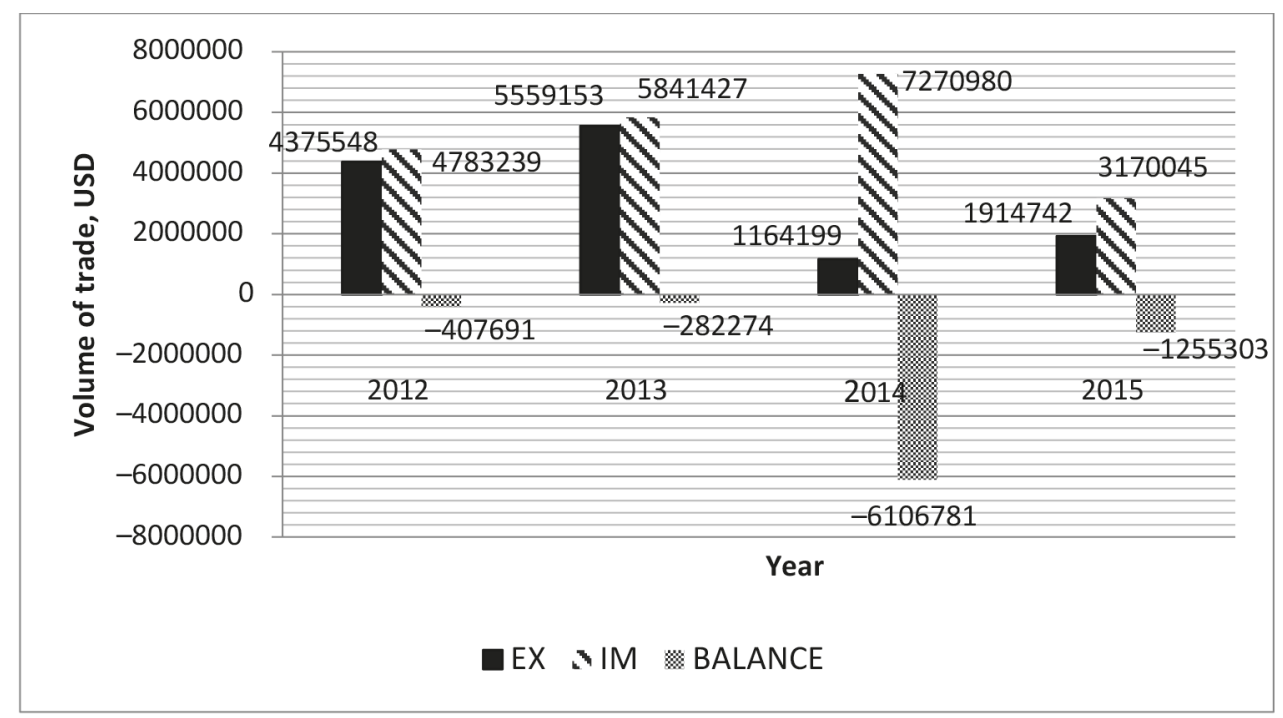

Figure 2. Russian 88 HS Code Commodities Trade Balance

Note: Compiled by the authors based on the information of ITC Trade Map Database: Trade Map Database // International Trade Centre. 2018. Available at: https://trademap.org/Index. aspx?AspxAutoDetectCookieSupport=1 (accessed: 15.02.2018).

At the beginning of 2017, the Vice President of United Aircraft Corporation Alexey Demidov said that the company's revenue increased by almost $40 \%$ for the previous two years. ${ }^{12}$ Revenue from domestic sales has decreased compared to the previous period, but it has been compensated by higher revenues from exports and maintenance services. Still, the volume of sales is not enough to cover total costs of SSJ-100 [Deliveries of SU-35..., 2017] and is unlikely to cause any distortions in the market.

Statistics show that Russian exports of 88 HS Code commodities have grown (Figure 2). The exports of aircraft, spacecraft, and parts thereof have been the only ones showing growth in exports in 2012-2013 compared to other manufactured products of 86, 87, and 89 HS codes. Although goods falling under the 86 and 87 HS codes have been subsidized as well, their exports have decreased almost three times and two times, respectively.

At the same time, one also sees an increase in imports of aviation products, which caused the negative balance of payments in 2014-2015. Here it is important to mention that such a change in trade flows could be explained by the turbulence of the Russian economy since these years. Moreover, although the program under consideration is targeted to help passenger aircraft producers, we need to take into account the fact, that this industry is strongly connected with military aircraft construction, which is demand-driven. Such demand is often the result of a political decision, rather than need for a balanced market situation. Further, the production of such complicated products is very often customized, takes a long time, and sometimes involves pre-payments, post-payments, or credit payment, while trade statistics reveals physical movement of goods across the border.

${ }^{12}$ Here it is worth to mentioning that there are other types of support provided by Russia in this industry. For instance, government procurement is one of the widely used instruments and also could affect the aviation development. However, as table 2 has already demonstrated, state aid plays a much more significant role in the Russian trade policy, that's why it became the main focus of the research. 
Due to the analysis of trade statistics, one could argue that this state aid program has not provided the expected effect of export promotion and development of local industry. Nevertheless, such a situation could be connected with the overall internal financial and economic problems of the country and not entirely with the program conditions. Therefore, we should say that as in the previous case, trade flows seem to be influenced by a large variety of external factors, although in the absence of the program under consideration, trade in aircraft could have had worse results. Taking into account the long-term perspective of this subsidy program, it is important to understand whether the mentioned state aid meets WTO rules ${ }^{13}$ and could have a trade distortion effect.

Although the Russia's Aviation Industry Development 2013-2025 program does not explicitly specify a group of enterprises or industries as potential beneficiaries of the program, there is an implicit limitation for the enterprises mentioned above as unique producers of these particular types of aircraft. As far as this state aid is not horizontal in nature, does not benefit Russian economy as a whole, and favors certain enterprises, they may be called specific in the WTO pursuant to Article 2.1(c) SCM Agreement. Subsidy specificity has great trade-distortion potential, because additional resources generated outside the company interfere in the market mechanism functioning, redistributing market-shares in favor of subsidies beneficiaries and at the expense of other players [Membership..., 2014].

While specific subsidies are prohibited by the WTO per se, one can argue that even in the absence of specificity there can be implied adverse effects on trade taking shape of a) material injury to the domestic industry of another WTO Member, b) nullification or impairment of benefits accruing directly or indirectly to other WTO Members connected with concessions bound under Article II GATT 1994, or c) serious prejudice to the interests of another Member of the WTO. Material injury is as a rule calculated on a case-bycase basis only; nullification or impairment connected with concessions granted under Article II GATT deal with the schedules of concessions on the importation of goods. This is not relevant in our case, and so we will analyze the conditions under which a subsidy may cause serious prejudice to an industry and try to assess whether such conditions may arise as a result of the program implementation.

If Russia's trade partners producing aircraft of the described type find that: 1) the imports of their product into the market of the Russian Federation is displaced or impeded, 2) the imports of their product into the market of a third country market is displaced or impeded, 3) a significant price undercutting by the subsidized aircraft originating from Russia as compared with the price of an aircraft produced by them or significant price suppression, or price depression or lost sales takes place in the same market, or 4) there is an increase of Russia's market share in the world market, then they could argue that this state aid program should be a subsidy prohibited according to the WTO. However, here we could see another challenge existing in the international regulation of state aid. To question whether the subsidy provided by one WTO Member has a trade distortion effect and doesn't meet the WTO rules, another WTO Members should provide the exhaustive evidence that is very resource consuming. This is why, as was already mentioned, the easiest way to struggle with the foreign state aid is to implement one's own. This explains the growing number of subsidy programs not only in BRICS states, but across the world.

${ }^{13}$ Russia is not a signatory to the Plurilateral agreement on trade in civil aircraft, which means that the analysis will not take that WTO agreement into account. 


\section{India: "Make in India" program}

"Make in India" is a recent program launched by India's Prime Minister in 2014 as a part of a wider set of initiatives. The global goal of the program - a response to decline in India's growth rate when the bubble of hyped emerging markets burst - is to transform India into a global design and manufacturing hub. "Make in India" covers a wide variety of sectors of the domestic economy: automobiles, automobile components, aviation, biotechnology, chemicals, etc. As a result of the program, India expects to be ranked among the world's top three growing economies and among the top five manufacturing destinations by 2020 [Make in India, 2018].

One of the sub-programs within the National Manufacturing Policy is aimed at creating National Investment and Manufacturing Zones (NIMZ) [National Manufacturing Policy, 2011], conceived as industrial greenfield townships intended to promote high-class manufacturing activities. The central government is to cover all costs of master planning, improving and providing external physical infrastructure (including rail, road, ports, airports, and telecom), and providing institutional infrastructure for productivity, skill development, and the promotion of domestic and global investments. Further, purchase preferences will be given to units in the national investment and manufacturing zones.

State-aid policies in automobile production and automobile components sectors are similar. A peculiar feature is that not only the central government and the states participate in the program as sponsors; industry and/or private sponsored research programs exist as well. They are granted tax exemptions in the form of a weighted tax deduction, concessional excise duty, as well as exemption from Basic Custom Duty (BCD) [Make in India, 2018]. Apart from the above-mentioned measures, some states in India offer additional incentives for industrial projects. Incentives are in such areas as rebates in land cost, relaxation of stamp duty, exemption on sale or lease of land, power tariff incentives, a concessional rate of interest on loans, investment subsidies/tax incentives, backward areas subsidies, and special incentive packages for mega projects.

The sector has had a positive trade balance with minor fluctuations, so we can suppose that incentives were provided not for the sake of rescuing of automotive industry, but for faster and steadier growth. Indian exports of vehicles, other than railway and tramway rolling stock, and parts and accessories thereof, have grown faster than anywhere else in the world, although the country's share in world exports is not very high. Falling imports may indicate an increase in the competitiveness of domestically-produced commodities at home. For 2012-2016, India's balance in trade of vehicles had significantly increased (Figure 3).

The automotive industry in India has been growing for the last two years in terms of domestic sales (passenger vehicles by $7.24 \%$, overall commercial vehicles by $11.51 \%$ ), production (increase by $2.6 \%$ ), and exports (increase by $1.91 \%$ ). Exports in the autocomponents sector are growing at a compound average growth rate of $18 \%$ over the last 6 years; the auto-component industry contributed $4 \%$ to India's exports in the 20152016 financial year [Automotive Sector..., 2016]. As the evidence suggests, there is a substantial increase in productivity and in both domestic trade and exports for the considered sectors, although it is difficult to estimate whether such success resulted from the program's implementation alone, or was a consequence of an improving economic situation as a whole. 


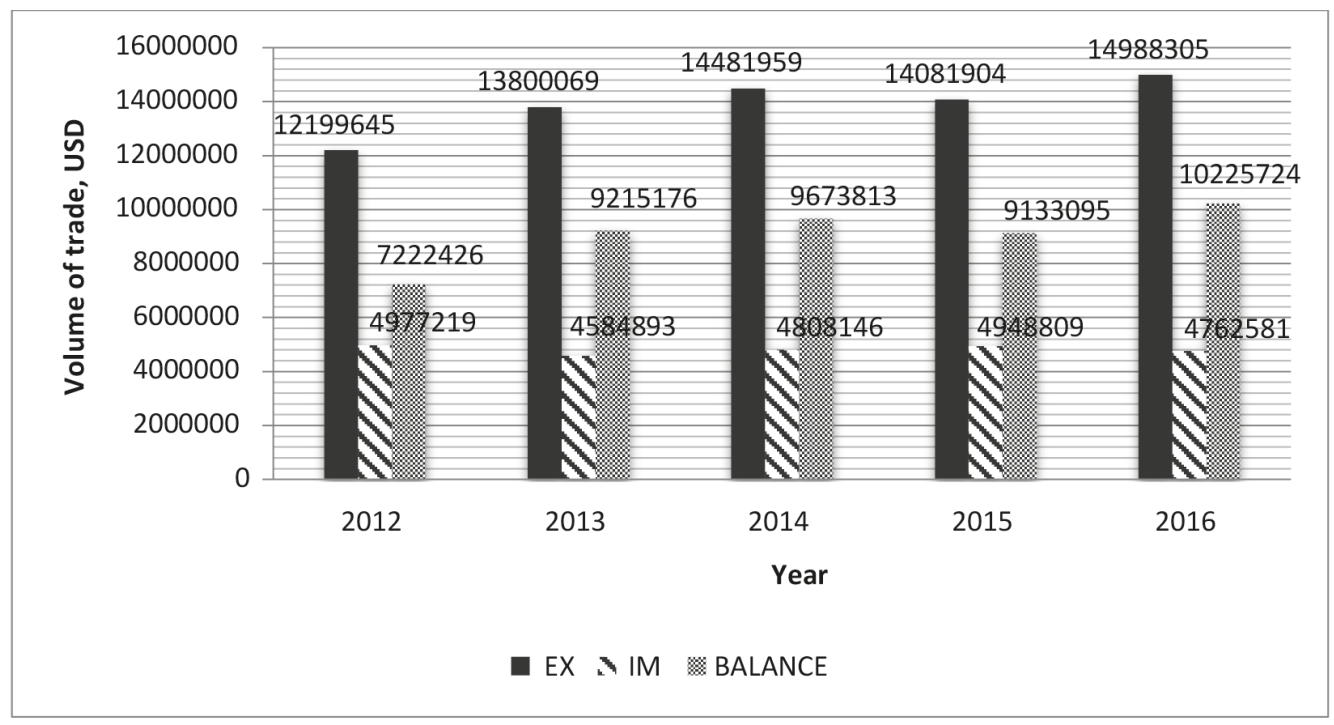

Figure 3. Indian 87 HS Code Commodities Trade Balance

Note: Compiled by the authors based on the information of ITC Trade Map Database: Trade Map Database // International Trade Centre. 2018. Available at: https://trademap.org/Index.aspx? AspxAutoDetectCookieSupport=1 (accessed: 15.02.2018).

The majority of incentives initiated by the Indian government were justified by their care of the environment, and opportunities for small and medium enterprises to enter the market and maintain their businesses or improve R \& D opportunities. India's subsidy program seems to be non-actionable, i.e. it does not give a valid reason to bring a case to DSM, since it was given as assistance to research activities conducted by firms, as well as to promote adaptation of existing facilities (Article 8 SCM Agreement). It is recognized that government assistance is widely provided by WTO members for various purposes, and even if such assistance may not qualify for non-actionable treatment, that does not restrict the ability of Members to provide such assistance. Even if subsidies are classified as actionable, they may have no negative effect on trade until the contrary is proved.

On the one hand, "Make in India" gives incentives for investments not only from domestic, but also foreign companies, and stimulates the development of manufacturing in general [Mehta, Rajan, 2017]. There is no discrimination under MFN and NT; however, the program has certainly increased the competitiveness of the Indian manufacturing sector. On the other hand, the results of industrial growth could be connected with the overall economic development of the country in recent years. Moreover, there is some skepticism about a substantial increase of production in India, as there are certain doubts about the existence of sufficient knowledge and a feasibility of growth in Indian automobile manufacturing [Sivasundaram Anushan et al., 2016; Sinha et al., 2017].

Thus, "Make in India" provides horizontal incentives to stimulate more or less proportionate changes throughout the whole economy. The program as a whole, if successful, may considerably increase competitiveness of Indian goods as well as their share in the world market. Therefore we view the program to be WTO consistent in general. 
In 2010 the Department of Trade and Industry of the Republic of South Africa worked out the Automotive Investment Scheme (AIS) as an incentive for growth in the automotive sector through investment in or replacement of models and components that will increase plant production volumes, sustain employment, and strengthen the automotive value chain [Automotive Investment..., 2017]. AIS provides for a non-taxable cash grant of $20 \%$ of the qualifying investment value in productive assets and $25 \%$ of the qualifying investment value in productive assets by component manufactures and tooling companies. An applicant must be a registered legal entity in South Africa and must undertake manufacturing in South Africa, and be a taxpayer in good standing.

However, there are certain requirements for producers who can benefit from the program. For instance, light motor vehicle manufacturers could apply for state aid if they can demonstrate that they will achieve a minimum of 50,000 annual units of production per plant within a three year period. An additional non-taxable cash grant of $5 \%$ may be made available for projects that maintain their base year employment figure throughout the incentive period, and achieve at least two of the following economic requirements: tooling; research and development in South Africa; employment creation; strengthening of the automotive value chain; value addition; and empowerment [Automotive Investment..., 2017]. The program also provides state aid to cover competitiveness improvement costs for component manufacturers, deemed component manufacturers, and tooling companies.

In general, South Africa's automotive industry is characterized by a poor business environment (over-regulation, lack of transparency, lack of effective enforcement) as well as frequent political and economic threats. There is also a low level of local research and development and electricity availability, as well as high costs for installing and maintaining domestic manufacturing facilities. Another challenge for the industrial development is unskilled labour. So far, the AIS program is limited in dealing with these issues. All these local problems, combined with other internal rigidities, create serious obstacles to stable sector development; and to make domestic producers successful in the world market, the government needs to overcome these problems, at least partially.

The rate of growth of South Africa's exports in the automotive sector is positive, showing results far better than the rest of the world on average. At the same time, total trade flows of the respective goods have fallen, meaning that the country's role in global trade in 87 HS Code goods has diminished. South African export growth was lower than the global average for the last five years; however, imports have significantly decreased in recent years (Figure 4).

The ultimate goal of the program is to attract more investment into the automotive manufacturing sector, but as a result of high costs of entering the market and the low level of productivity and competitiveness, large multinational firms do not include African countries into their global value chains [Hoekman, 2013]. Experts argue that incentives of South Africa's state aid program are insufficient for industrial development [Stein, 2013].

The analysis of the WTO-consistency shows, that there is no reason to believe that AIS may cause trade distortions, since there is no evidence that the provision of subsidies is contingent upon export performance or upon the use of domestic over imported goods. Neither do we believe that the program can cause an injury to the domestic industry of 


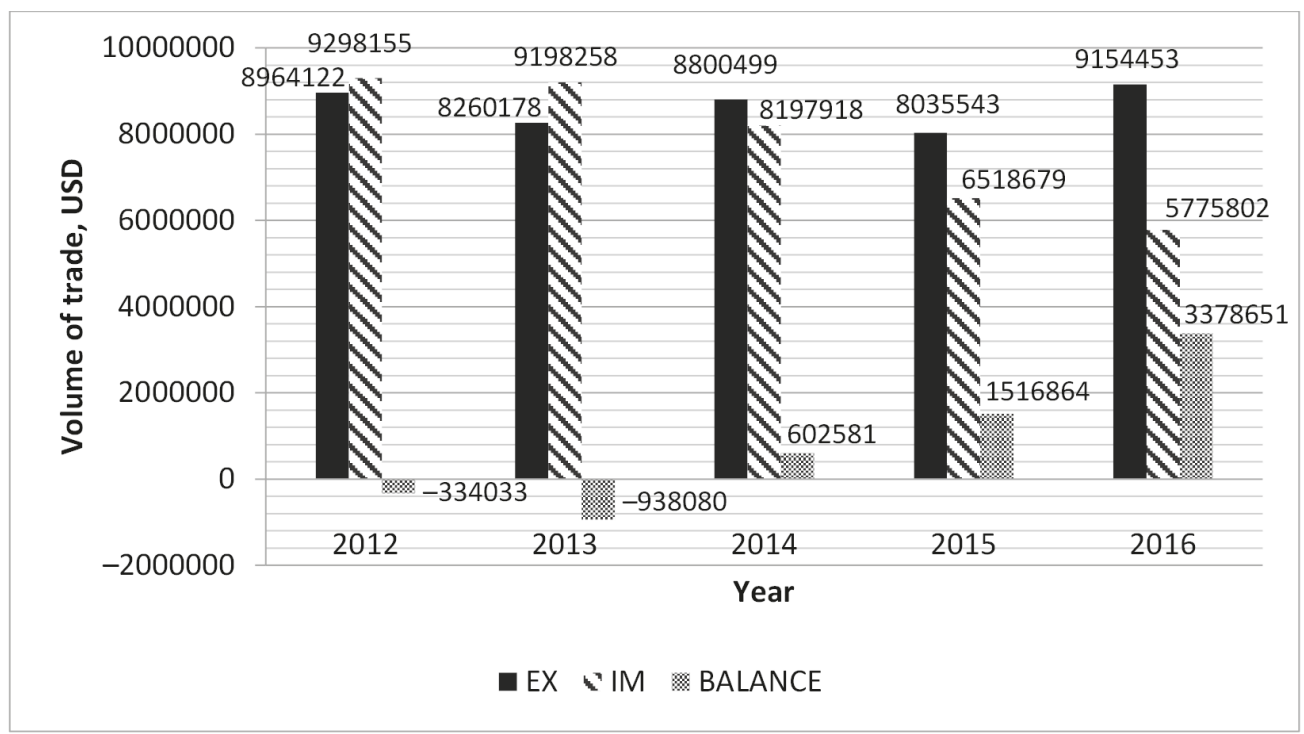

Figure 4. South African 87 HS Code Commodities Trade Balance

Note: Compiled by the authors based on the information of ITC Trade Map Database: Trade Map Database // International Trade Centre. 2018. Available at: https://trademap.org/Index.aspx?AspxAutoDetectCookieSupport=1 (accessed: 15.02.2018).

any South African trade partner, or seriously prejudice the interests of any trade partner. Some doubt may be cast on the question of whether the program limits the number of its beneficiaries. Since the program requires certain production performance norms to be fulfilled, we suppose that these requirements could fall under the definition of "the manner in which discretion has been exercised by the granting authority in the decision to grant a subsidy" outlined in Article 2 para 1(c) SCM Agreement. However, it seems that the program alone may not invoke a real threat to international trade and create unfair competition with the help of the used non-market mechanisms.

Table 4 presents the comparison of conducted case-studies. The vertical import-substitution subsidy (as it privileges domestic over foreign goods) presents the most substantial import decline, demonstrating the increase of competitiveness of domestic producers on national markets. However, such a subsidy did not lead to export growth in comparison to other cases, which raises the question as to whether domestic producers could maintain competitiveness without protection in the long run. The Brazilian state aid evidently is WTO-inconsistent, which leads to a sufficient trade distortion effect and discontent by trade partners. Thus, the possibility of initiation a dispute against import-substitution subsidies under the WTO is high, that brings additional costs to the state.

Import decline could be also achieved by vertical specific subsidies provided by Russia and South Africa. This type of state aid is less risky, as the trade distortion effect is less obvious and the analysis of WTO-consistency requires more studies by affected trade partners. However, both Russia and South Africa provided state aid in the form of grants that could clearly be defined as direct subsidies. Positive changes in trade balance under vertical specific subsidies are also not obvious, as was demonstrated by the Russian case. The results of state aid implementation are highly influenced by other macroeconomic and institutional factors. 
Table 4. BRICS state aid: comparative analysis of case studies

\begin{tabular}{|c|c|c|c|c|c|c|}
\hline Country & Program & Sector & $\begin{array}{c}\text { Main } \\
\text { instruments }\end{array}$ & $\begin{array}{c}\text { Type } \\
\text { of state aid }\end{array}$ & $\begin{array}{c}\text { WTO } \\
\text { consistency }\end{array}$ & $\begin{array}{l}\text { Trade balance } \\
\text { improvement }\end{array}$ \\
\hline Brazil & $\begin{array}{l}\text { INOVAR- } \\
\text { Auto }\end{array}$ & 87 & $\begin{array}{l}\text { Tax reduction } \\
\text { on domestic } \\
\text { goods and } \\
\text { for certain } \\
\text { companies }\end{array}$ & $\begin{array}{l}\text { Vertical } \\
\text { Import- } \\
\text { substitution } \\
\text { subsidy }\end{array}$ & No & $\begin{array}{l}\text { Yes, due } \\
\text { substantial } \\
\text { import decline }\end{array}$ \\
\hline Russia & \begin{tabular}{|l|} 
Aviation \\
Industry \\
Development \\
$2013-2025$
\end{tabular} & 88 & $\begin{array}{l}\text { Coverage of } \\
\text { some costs } \\
\text { for specific } \\
\text { companies }\end{array}$ & $\begin{array}{l}\text { Vertical } \\
\text { specific subsidy }\end{array}$ & $\begin{array}{l}\text { No, if proved } \\
\text { a serious } \\
\text { prejudice to } \\
\text { trade partners' } \\
\text { interests }\end{array}$ & $\begin{array}{l}\text { Only slight } \\
\text { effect in the } \\
\text { short-run }\end{array}$ \\
\hline India & $\begin{array}{l}\text { Make in } \\
\text { India }\end{array}$ & $\begin{array}{l}\text { All } \\
\text { manufacturing } \\
\text { sectors, } \\
\text { including } 87\end{array}$ & $\begin{array}{l}\text { Tax exemption, } \\
\text { low loans rates, } \\
\text { power tariff } \\
\text { incentives, } \\
\text { special support } \\
\text { of R\&D, } \\
\text { backward areas } \\
\text { and mega } \\
\text { projects }\end{array}$ & $\begin{array}{l}\text { Horizontal } \\
\text { subsidy }\end{array}$ & Yes & $\begin{array}{l}\text { Yes, due to } \\
\text { export increase } \\
\text { and import } \\
\text { decline }\end{array}$ \\
\hline $\begin{array}{l}\text { South } \\
\text { Africa }\end{array}$ & \begin{tabular}{|l|} 
Automotive \\
Investment \\
Scheme (AIS)
\end{tabular} & 87 & $\begin{array}{l}\text { Non-taxable } \\
\text { cash grants } \\
\text { for specific } \\
\text { companies }\end{array}$ & $\begin{array}{l}\text { Vertical } \\
\text { specific subsidy }\end{array}$ & $\begin{array}{l}\text { No, if proved a } \\
\text { material injury } \\
\text { or a serious } \\
\text { prejudice to } \\
\text { trade partners' } \\
\text { interests }\end{array}$ & $\begin{array}{l}\text { Yes due to } \\
\text { import decline } \\
\text { and slight } \\
\text { export growth }\end{array}$ \\
\hline
\end{tabular}

N o t e: Compiled by the authors on the basis of case-studies.

The only case that could be presented as WTO-consistent was a horizontal subsidy implemented by India. While this program also included tax exemption as in the Brazilian case, there was no discrimination of foreign producers directly, and it also provides a variety of state aid measures. The trade balance was improved by both import decline and export growth. The Indian experience demonstrates that a more comprehensive state aid program, including different incentives, can have less of a trade distortion effect, while improving the trade balance. Further study and development of horizontal state aid could, on the one hand, help policy makers to introduce subsidy programs with a higher level of complexity. On the other hand, it will most probably make it more difficult to indicate a trade distortion effect and require a more comprehensive analysis of subsidies by affected trade partners in particular and the WTO in general.

\section{Conclusion}

Subsidization is a macroeconomic measure that allows adjusting the economic performance of an enterprise or industry to the real market situation or urgent needs of society, but all the potential costs and benefits should be scrutinized beforehand in order to 
avoid sporadic creation of new market externalities. State aid are non-tariff measures often used by BRICS as well as other countries.

Comparison of BRICS trade policies indicated the complex nature of this phenomenon, as it was influenced by a variety of internal and external factors and in line with the country's foreign policy development program, obligations to its citizens, and the world economic community. Evidence suggests that all BRICS members actively use protectionist trade policies in the form of non-tariff barriers to augment the effect of tariff reductions undertaken as a result of WTO accession.

The examination of several subsidy programs confirmed our hypothesis that certain state aid programs create a trade diversion effect on international trade in transport equipment (the most obvious case was Brazil) and incentivize exports, and undermine BRICS's claims to pursue trade liberalization. Although violation of WTO legislation does not necessarily mean the existence of a trade diversion effect, the latter is still likely. At the same time, we concluded that the economic environment as a whole has no less important an effect: poor economic performance can hardly be overcome by a single vertical subsidy program.

Under the outlined subsidy programs, state aid is provided ex-ante; governments would like to prevent the appearance of any critical situation in transport equipment manufacturing because of the sector's high strategic importance. The conditions of state aid provision assume results of the programs' potential beneficiaries' activity, rather than resource allocation (except for Brazil), which implies potentially high long-term costs.

The ultimate target of initiating such state aid programs is not production growth alone, but also export incentive to improve competitiveness of locally produced goods in the global market for transportation equipment. The program initiated by the Russian Federation is the only one that presupposes de facto subsidization of certain enterprises, and it has not been all that effective at achieving export growth. Although the provision of horizontal subsidies ("Make in India" initiative) is praised by the international trade system, it incurs enormous costs and in our case resulted in increased efficiency and larger trade flows mainly because of the favorable environment for the sector at the outset of the initiative.

The modalities of participation in these programs are rather transparent, and no obvious loopholes distorting competitive participation of potential beneficiaries were revealed in the course of the analysis. A substantial disadvantage of all the programs is that none of them imvolves periodic reassessment of beneficiaries' achievements and comparison of established goals with achieved results.

Therefore, ceteris paribus, authorities trying to adjust terms of state aid provision to their international obligations making their subsidy program as innocuous as possible (horizontal application of subsidies) place a heavy burden of cost coverage on society and risks failing to achieve initial goals. At the same time, governments oriented to satisfy domestic needs and neglecting international obligations are likely to achieve better results from targeted financial provision (vertical application of subsidies). Comparing trade diversion and trade creation possibilities from horizontal and vertical subsidy programs opens a new field for future research. 


\section{References}

Abbott P. C., Paarlberg P. L., Sharples J.A. Targeted agricultural export subsidies and social welfare. American Journal of Agricultural Economics, 1987, vol. 69, no. 4, pp. 23-32.

Automotive Investment Scheme Guidelines. The Department of Trade and Industry: Trade and Industry of South Africa. August 2017. Available at: https://www.thedti.gov.za/DownloadFileAction?id=1181\&filename=A IS. pdf (accessed: 15.02.2018).

Automotive Sector. Achievements Report. Department of Industrial Policy and Promotion \& Department of Heavy Industries. 26.11.2016. URL: http://www.makeinindia.com/documents/10281/114126/ Automotive+Sector+-+Achievement+Report+\%281\%29.pdf (accessed: 15.02.2018).

Baldwin R., Evenett S. The collapse of global trade, murky protectionism, and the crisis: Recommendations for the G20. London: CEPR, 2009. $112 \mathrm{p}$.

Barone B., Bendini R. Protectionism in the G20. Brussels: European Union, 2015. 41 p.

Biller D. Goldman Warns of Brazil Depression After GDP Plunges Again. Bloomberg. Business. 01.12. 2015. Available at: https://www.bloomberg.com/news/articles/2015-12-01/brazil-gdp-falls-more-than-analysts-expected-as-demand-withers (accessed: 15.02.2018).

Brazil - Certain Measures Concerning Taxation and Charges. WTO Panel Report, WT/DS472/R, WT/ DS497/R, 30.08.2017. Available at: https://www.wto.org/english/tratop_e/dispu_e/472_497r_e.pdf (accessed: 15.02.2018).

BRICS Leaders Xiamen Declaration, 04.09.2017. Ministry of Foreign Affairs of the People's Republic of China. 09.08.2017. Available at: https://www.brics2017.org/English/Documents/Summit/201709/ t20170908_2021.html (accessed: 15.02.2018).

Chlenstvo v VTO: novyi etap uchastiia Rossii v mezhdunarodnoi torgovoi sisteme: monografiia 2-e izd., pererab. i dop. [Membership in the WTO: a new stage of Russia's participation in the international trading system]. $2^{\text {nd }}$ ed. Eds S. Sutyrin, O. Trofimenko. Moscow, Prospect, 2014. 264 p. (In Russian)

Collie D. R. State aid in the European Union: The prohibition of subsidies in an integrated market. International Journal of Industrial Organization, 2000, no. 18, pp. 867-884.

Competition, State Aids and Subsidies. Policy Roundtables. OECD. 19.05.2011. Available at: http://www.oecd. org/competition/sectors/48070736.pdf (accessed: 15.02.2018).

Competition. State Aid. State Aid Control. European Commission. 12.09.2016. Available at: http://ec.europa.eu/ competition/state_aid/overview/index_en.html (accessed: 15.02.2018).

Deardorff A.V. Terms of trade: glossary of international economics. $2^{\text {nd }}$ edition. New Jersey: World Scientific Publishing Company, 2014. 396 p.

DS472: Brazil - Certain Measures Concerning Taxation and Charges. WTO Dispute Settlement. 27.11.2017. Available at: https://www.wto.org/english/tratop_e/dispu_e/cases_e/ds472_e.htm (accessed: 15.02.2018).

Evenett S. J. BRICS Trade Strategy: Time for a Rethink. The $17^{\text {th }}$ Global Trade Alert Report, 2015. Available at: http://www.globaltradealert.org/reports/download/22 (accessed: 15.02.2018).

Exploring the links between subsidies, trade and the WTO. World Trade Report. World Trade Organization (WTO), 2006. Available at: https://www.wto.org/english/res_e/booksp_e/anrep_e/world_trade_ report06_e.pdf (accessed: 15.02.2018).

Feenstra R. Trade policy with several goods and market linkages. Journal of International Economics, 1986, no. 20 , pp. $249-267$.

Ginevicius R., Podvezko V., Bruzge S. Evaluating the effect of state aid to business by multicriteria methods. Journal of Business Economics and Management, 2010, vol. 9, iss. 3, pp. 167-180.

Global Manufacturing Competitiveness Index Report. Deloitte Touche Tohmatsu Limited and US Council on Competitiveness, 2016. Available at: https:/www2.deloitte.com/content/dam/Deloitte/global/Documents/ Manufacturing/gx-global-mfg-competitiveness-index-2016.pdf (accessed: 15.02.2018).

Głowicka E. State Aid and Competition Policy: The Case of Bailouts in the EU. Dissertation. Humboldt-Universität zu Berlin, 2008. 113 p.

Heima S., Hüschelrath K., Schmidt-Dengler Ph., Strazzeri M. The impact of state aid on the survival and financial viability of aided firms. European Economic Review, 2017, vol. 100, pp. 193-214.

Hoekman B. Adding Value. Finance \& Development, 2013, vol. 50, no. 4, pp. 22-24.

Houthakker H.S. The control of special benefit programs. US Congress. Joint Economic Committee. The Economics of Federal Subsidy Programs - A Compendium of Papers. $92^{\text {nd }}$ Congress. $2^{\text {nd }}$ Session. Washington: Government Printing Office. 1972, pp. 7-12.

INOVAR-Auto. Programa de Incentivo à Inovação Tecnológica e Adensamento da Cadeia Produtiva de Veículos Automotores. 17.12.2012. Available at: http://inovarauto.mdic.gov.br/InovarAuto/public/inovar.jspx?_ adf.ctrl-state=wt19obqz6_14 (accessed: 15.02/2018). 
Koval A.G., Pioch M. Strany BRIKS v global'nom ekonomicheskom upravlenii na primere ikh uchastiia v VTO [BRICS states in the global economic governance: the WTO case]. Vestn. Volgograd.o gos. un-ta. Seriia 2. Ekonomika. Ekologiia [Science Journal of Volgograd State University: Global Economic System], 2017, vol. 38, no. 1, pp. 111-121. (In Russian)

Koval A. G., Trofimenko O. Y. Rol' BRIKS vo vneshnetorgovoi politike Rossii [BRICS role in the Russian foreign trade policy]. Mezhdunarodnaia ekonomika, 2017, no. 10, pp. 20-29. (In Russian)

Make in India. 2018. Available at: http://www.makeinindia.com/home (accessed: 15.02.2018).

Mehta Y., Rajan A. J. Manufacturing Sectors in India: Outlook and Challenges. Procedia Engineering, 2017, vol. 174, pp. 90-104.

Meiklejohn R. The economics of State aid. State Aid and the Single Market, European Economy. Vol.3. Brussels, European Commission. 1999, pp. 25-31.

Mello A.M., Marx R., Mota F.G. A preliminary analysis of Inovar Auto impact on the Brazilian Automotive Industry R \& D activity. Revista de Administração e Inovação, 2016, no. 13, pp. 22-28.

Messerlin P. External Aspects of State Aid. State Aid and the Single Market, European Economy. Vol. 3. Brussels, European Commission. 1999, pp. 161-195.

National Manufacturing Policy. Ministry of Commerce and Industry, Government of India, Press Note No. 2. 04.11.2011. Available at: http://dipp.nic.in/sites/default/files/National_Manufacturing Policy_25October2011.pdf (accessed: 15.05.2018).

Naude W. A., Szirmai A., Haraguchi N. Structural Change and Industrial Development in the BRICS. Oxford, Oxford University Press, 2015. 492 p.

Pascoal E. T., Delamaro M. C., Ibusuki U., Tsukada O., Roch H. M. The new Brazilian automotive policy and its impact on the competitiveness of multinational automobile and auto parts manufacturers. International Journal of Automotive Technology and Management, 2017, vol. 17, iss. 3, pp. 225-247.

Pereira L., Plonski G. A. Shedding light on technological development in Brazil. Technovation, 2009, vol. 29, iss. 6-7, pp. 451-464.

Pioch M. BRICS in trade clusters: the prospects of convergent trade policies of large emerging economies. St Petersburg University Journal of Economic Studies, 2017, vol.33, iss. 2, pp. 282-302.

Poluektov A. B. Programmy RF po podderzhke promyshlennogo eksporta: nekotorye nabliudeniia [Program of the Russian Federation on support of industrial export: some observations]. Torgovaia politika [Trade policy], 2015, no. 2, pp. 174-183. (In Russian)

Postavki Su-35, Su-30 i SSJ100 vpervye prinesli OAK pribyl' v 1 mlrd. rub. [Deliveries of SU-35, SU-30 and SSJ100 for the first time brought UAC profit of 1 billion rubles]. Rossiiskaia gazeta. 03.04.2017. Available at: https://rg.ru/2017/04/03/postavki-su-35-su-30-i-ssj100-vpervye-prinesli-oak-pribyl-v-1-mlrd-rub. html (accessed: 15.02.2018). (In Russian)

Realizing the BRICS long-term goals: Road-maps and pathways. A proposal by the BRICS Think Tanks Council. Observer Research Foundation (ORF), 2017. Available at: http://www.nkibrics.ru/system/asset_publications/data/595a/0f00/6272/6948/82d5/0000/original/Realizing_the_BRICS_Long-Term_Goals._RoadMaps_and_Pathways._A_proposal_by_the_BRICS_Think_Tanks_Council..pdf?1499074302 (accessed: 15.02.2018).

Report from the Commission to the European Parliament and the Council under Article 7 of Decision 2006/500/ EC (Energy Community Treaty). European Commission. 10.03.2011. Available at: https://eur-lex.europa. $\mathrm{eu} /$ legal-content/EN/TXT/HTML/?uri=CELEX:52011DC0105\&from=en (accessed: 15.02.2018).

Resolution of March 31, 2017 No. 379 «On Amendments to the State Programme of the Russian Federation "Development of Aviation Industry in 2013-2025”». 139 p. Available at: http://static.government.ru/media/files/ GUAUVHfGtBGzSAqmMXAHb0jXx1CNlwaI. pdf (accessed: 15.02.2018).

Rubini L. The Definition of Subsidy and State Aid: WTO and EC Law in Comparative Perspective. Oxford, Oxford University Press, 2009. 448 p.

Sambo S., Orr E., Godboy D. Brazilian Real Drops to Record Low Against U.S. Dollar. Bloomberg. 2015. Available at: https://www.bloomberg.com/news/articles/2015-09-22/brazil-s-currency-tumbles-to-record-onpessimism-over-budget (accessed: 15.02.2018).

Schwartz G., Clements B. Government Subsidies. Journal of Economic Surveys, 1999, no. 13(2), pp. 119-147.

Sciskalova M., Muenster M. Definition and Characteristics of State Aid. Procedia. Social and Behavioural Sciences, 2014, no. 110, pp. 223-230.

Shah A. Economic Rationale, Subsidy and Cost Sharing in Watershed projects. Economic and Political Weekly, 2005, vol. 40, no. 26, pp. 2663-2671.

Sinha A., Mondal S., Boone T., Ganeshan R. Analysis of issues controlling the feasibility of automobile remanufacturing business in India. International Journal of Services and Operations Management, 2017, vol. 26, iss. 4 , pp. $459-475$. 
Sivasundaram Anushan S. C., Anbarasu P., Naveen A. J. A., Pandi K. S. Model of Make in India Possibilities: An Indian Operations Dream. Indian Journal of Science and Technology, 2016, vol. 9, iss. 27, pp. 1-10.

Stein L. SA motor incentives insufficient. Guardian, 11.10.2013. Available at: https://mg.co.za/article/201310-11-00-sa-motor-incentives-insufficient (accessed: 15.02.2018).

Sturgeon T., Chagas L.L., Barnes J. Inovar Auto: Evaluating Brazil's Automative Industrial Policy to Meet the Challenges of Global Value Chains. Background paper, World Bank Group, 2017. Available at: https:// openknowledge.worldbank.org/bitstream/handle/10986/28947/121667-REVISED-Brazil-Public-Expenditure-Review-Brazil-in-Automotive-Globa.pdf?sequence=1\&isAllowed=y (accessed: 15.02.2018).

Trade and public policies: A closer look at non-tariff measures in the $21^{\text {st }}$ century. World Trade Organization (WTO). World Trade Report. Geneva, WTO, 2012. 247 p.

Transport Equipment in Asia Pacific, Strategic Briefing. Euromonitor. January 2018. Available at: http://www. euromonitor.com/transport-equipment-in-asia-pacific/report (accessed: 15.02.2018).

Zahariadis N. State Subsidies in the Global Economy. New York, Palgrave MacMillan, 2008. 193 p.

Received: May 3, 2018

Accepted: June 25, 2018

Author's information:

Alexandra G. Koval — PhD in Economics, Associate Pprofessor; a.koval@spbu.ru

Anastasia B. Mogucheva - MA in Economics; anastasya.mogucheva@mail.ru

\title{
Программы государственной помощи в странах БРИКС на примере торговли транспортным оборудованием ${ }^{*}$
}

\author{
А. Г. Коваль, А. Б. Могучева \\ Санкт-Петербургский государственный университет, \\ Российская Федерация, 199034, Санкт-Петербург, Университетская наб., 7-9
}

Для цитирования: Koval A.G., Mogucheva A.B. State-aid programs of BRICS countries: Case of transport equipment trade // Вестник Санкт-Петербургского университета. Экономика. 2018. Т. 34. Вып. 3. С. 415-438. https://doi.org/10.21638/spbu05.2018.304

Программы государственной помощи (субсидии) являются достаточно распространенной формой поддержки национальных компаний в развитых и развивающихся странах. Хотя эти меры строго регулируются правилами ВТО, государства БРИКС активно их используют, несмотря на заявления о стремлениях к либерализации и торговому сотрудничеству. Целью статьи является определение отличительных характеристик данных программ в странах БРИКС в сфере торговли транспортным оборудованием. Методы исследования базируются на межстрановом сравнительном анализе и изучении отдельных кейсов. В первой части статьи авторы выделяют противоречия, существующие в теоретических подходах к анализу программ государственной помощи. Вторая часть посвящена описанию особенностей применения нетарифных мер в странах БРИКС и роли государственной помощи. И в завершение анализа представлены конкретные кейсы в области торговли транспортным оборудованием. Авторы пришли к выводу, что результативность субсидий в транспортном секторе не столь очевидна, поскольку на динамику импорта и экспорта соответствующей продукции влияют весьма разнообразные внешние факторы. Тем не менее применение программ государственной помощи приводит к созданию более благоприятных условий для на-

* Исследование выполнено при поддержке РФФИ, проект №17-02-00688 «Трансформация внешнеэкономической политики России в меняющихся геополитических условиях». 
циональных производителей. Данные программы в большинстве случаев не соответствуют правилам ВТО, что формирует дисбаланс в международной торговле и несет в себе угрозу инициирования споров. В странах БРИКС необходимо усилить мониторинг данных программ и обратить внимание на возможность использования прежде всего горизонтальных, нежели вертикальных субсидий.

Ключевые слова: государственная помощь, субсидия, нетарифные меры, БРИКС, протекционизм, внешняя торговля, торговля транспортным оборудованием.

Контактная информация:

Коваль Александра Геннадьевна - канд. экон. наук, доц.; a.koval@spbu.ru Могучева Анастасия Борисовна - магистр экономики; anastasya.mogucheva@mail.ru 